\title{
Analysis of the Performance of 11 Formulae for Fetal Weight Estimation in Preterm Fetuses with Abnormal Doppler Velocimetry - A Retrospective Multicenter Study
}

\section{Análise do desempenho de 11 fórmulas de estimativa de peso fetal em conceptos prematuros com Dopplervelocimetria alterada - um estudo retrospectivo multicêntrico}

\begin{abstract}
Alessandra Martins Heringer de Lima ${ }^{1}$ Paulo Roberto Nassar de Carvalho ${ }^{1,2}$ Saint Clair Gomes Junior ${ }^{2}$ Ana Carolina Costa Carioca ${ }^{2}$ José Maria de Andrade Lopes ${ }^{1,2}$

1 Diagnostic Center, Clínica Perinatal Laranjeiras, Rio de Janeiro, RJ, Brazil

2 Fetal Medicine Center, Instituto Nacional Fernandes Figueira,

Fundação Oswaldo Cruz, Rio de Janeiro, RJ, Brazil

Address for correspondence Alessandra Martins Heringer de Lima, Master, Centro Diagnóstico, Clínica Perinatal Laranjeiras, Rua das Laranjeiras, 445, 22240-002, Laranjeiras, Rio de Janeiro, RJ, Brazil (e-mail: alemheringer@gmail.com).
\end{abstract}

Rev Bras Ginecol Obstet 2018;40:580-586.

\begin{abstract}
Objective To assess 11 formulae commonly used to estimate fetal weight in a population of premature fetuses who had abnormal Doppler velocimetry due to early-onset placental insufficiency. The performance of each formula was evaluated in subgroups of fetuses with expected growth and intrauterine growth restriction.

Methods Data were collected from fetuses and mothers who delivered at three Brazilian hospitals between November 2002 and December 2013. We used the following formulae: Campbell; Hadlock I, II, III, IV and V; Shepard; Warsof; Weiner I and II; and Woo III.

\section{Keywords}

- fetal weight

- birth weight

- premature birth

- ultrasound

- prenatal ultrasound

- doppler ultrasound

- fetal growth retardation

- placental insufficiency

Results We analyzed 194 fetuses. Of these, 116 (59.8\%) were considered appropriate for gestational age (AGA), and 103 (53.1\%) were male. The amniotic fluid volume was reduced in 87 (44.8\%) fetuses, and the umbilical artery Doppler revealed absence or inversion of diastolic flow in 122 (62.9\%) cases, and the analysis of the ductus venosus revealed abnormal flow in 60 (34.8\%) fetuses. The Hadlock formulae using three or four fetal biometric parameters had low absolute percentage error in the estimated fetal weight among preterm fetuses with abnormal Doppler studies who were born within 5 days of the ultrasound evaluation. The results were not influenced by the clinical and ultrasound parameters often found in early-onset placental insufficiency.

Conclusion In this study, the formulae with the best performance for fetal weight estimation in the analyzed population were Hadlock I and IV, which use four and three fetal biometric parameters respectively to estimate the weight of preterm fetuses with abnormal Doppler studies.
\end{abstract}

received

January 22, 2018

accepted

June 12, 2018

published online

September 20, 2018
DOI https://doi.org/

10.1055/s-0038-1670643.

ISSN 0100-7203.
Copyright (e 2018 by Thieme Revinter

Publicações Ltda, Rio de Janeiro, Brazil
License terms

(c) (1) 


\section{Resumo}
Palavras-chave
- peso fetal
- peso ao nascer
- parto prematuro
- ultrassonografia
- ultrassonografia pré-natal
- ultrassonografia doppler
- retardo do crescimento fetal
- insuficiência placentária

Objetivo Avaliar o desempenho de 11 fórmulas comumente utilizadas para estimativa de peso fetal em uma população de fetos prematuros com dopplervelocimetria alterada devido a insuficiência placentária de início precoce. O desempenho de cada fórmula foi avaliado em subgrupos de fetos com crescimento adequado e com crescimento intrauterino restrito.

Métodos Foram coletados os dados de mães e fetos cujos partos foram acompanhados em 3 instituições brasileiras entre novembro de 2002 e dezembro de 2013. As fórmulas selecionadas para análise foram: Campbell; Hadlock I, II, III, IV e V; Shepard; Warsof; Weiner I e II; e Woo III.

Resultados Foram analisados os pesos de 194 fetos, dos quais $116(59,8 \%)$ foram considerados adequados para a idade gestacional, 103 (53,1\%) eram do sexo masculino, em 87 (44,8\%) havia redução do volume de líquido amniótico, em 122 (62,9\%) o Doppler de artéria umbilical demonstrou ausência ou inversão do fluxo na diástole, e em $60(34,8 \%)$ a análise do duto venoso indicou fluxo anormal. A média do erro percentual absoluto (EPA) demonstrou que as fórmulas de Hadlock que utilizam 3 ou 4 parâmetros biométricos fetais apresentaram o melhor desempenho. Os resultados obtidos para essas fórmulas não sofreram influência dos parâmetros clínicos e ultrassonográficos frequentemente encontrados na insuficiência placentária de início precoce.

Conclusão O presente estudo demonstrou o melhor desempenho das fórmulas de Hadlock que contêm 3 ou 4 parâmetros da biometria para estimativa de peso de fetos prematuros com anormalidades ao mapeamento Doppler.

\section{Introduction}

The accuracy of fetal weight estimation is very important for patients who have intrauterine growth restriction (IUGR). When IUGR occurs at the threshold of neonate viability, accurate fetal weight estimation represents a valuable predictive factor to assess the probability of perinatal survival. Precise weight prediction before birth may minimize the perinatal morbidity and mortality associated with lower intrauterine growth. ${ }^{1}$

The normal development of the placenta, which occurs in the early stages of gestation, is dependent on the adequate invasion of trophoblastic cells in the decidual and myometrial segments of the spiral uterine arteries, which represent the most important source of irrigation in the uterine body region. ${ }^{2-4}$ Impaired trophoblast invasion (or abnormal placental implantation) is associated with elevated vascular resistance in the fetal-placental and uteroplacental circulation, and, consequently, with the development of preeclampsia and IUGR, a condition called placental insufficiency. 5,6

The reduction of fetal systemic blood flow due to fetal compensatory mechanisms in placental insufficiency leads to a decrease in the fetal growth rate. ${ }^{7}$ When these events lead to gestation in the second or early third trimesters, we call this early-onset placental insufficiency, and its severity is directly proportional to gestational age (GA), estimated fetal weight (EFW) and alterations found in Doppler mapping. ${ }^{7}$ Intrauterine growth restriction is a major consequence of placental insufficiency, and constitutes a significant public health problem, increasing the rates of neonatal morbidity and mortality and late postnatal consequences. ${ }^{3,4}$ In general, this fetal pathology is a common clinical issue, present in 7 to $15 \%$ of all pregnancies. ${ }^{8}$

The perinatal outcome of fetuses affected by placental insufficiency is broadly dependent on the severity of the growth restriction, and EFW below the third percentile and/ or abnormal findings in the umbilical artery (UA) represent the greatest risks for adverse perinatal results. ${ }^{8-11}$ Other important prenatal determinants for the perinatal outcome are GA at birth and birth weight (BW), which is traditionally used as a predictive parameter of neonatal survival. ${ }^{11}$

Most EFW ultrasound formulae have been evaluated in multiple clinical conditions, but there is criticism of the indiscriminate use of these models in situations such as IUGR triggered by early-onset placental insufficiency. Only the Hadlock formula with four fetal biometric parameters (head circumference $[\mathrm{HC}]$, abdominal circumference $[\mathrm{AC}]$, femur length [FL] and biparietal diameter [BPD]) was tested in the population with altered Doppler velocimetry and high risk for IUGR. ${ }^{12}$

The present study aimed to assess the performance of 11 ultrasound formulae used to estimate fetal weight in premature fetuses with arterial and venous blood flow changes identified through Doppler velocimetry.

\section{Methods}

Data were collected from a cohort of women and their fetuses submitted to ultrasound and Doppler velocimetry examinations who delivered at one of three maternity hospitals in the 
Rio de Janeiro metropolitan area: Instituto Fernandes Figueira, Clínica Perinatal Barra, and Clínica Perinatal Laranjeiras, between November 2002 and December 2013.

The inclusion criteria were: women on the 24th to 33rd weeks of pregnancy, calculated according to the date of the last menstrual period and confirmed through obstetric ultrasonography performed by the 20th week of pregnancy; presence of Doppler velocimetry levels compatible with fetal blood flow redistribution (increase of the pulsatility index [PI] of the UA above the 95th percentile for GA; presence of brain sparing reflex, with PI of the middle cerebral artery [MCA] below the 5th percentile for GA; AU with zero or reverse diastole in the $U A$ ); interval between the last ultrasound assessment of fetal biometry and birth not longer than five days; interval between last Doppler velocimetry exam and delivery not longer than 24 hours; and absence of signs of infection.

The exclusion criteria were multiple pregnancies, presence of fetal malformation assessed through prenatal care and/or confirmed on physical examination immediately after birth, and lack of reliable or available data to satisfy data collection.

Doppler velocimetry and ultrasonography were performed using the following devices: General Electric Voluson E6, and General Electric Voluson S6 (Boston, MA, US). All of the ultrasound examiners had at least two years of experience in obstetric examinations, and were certified by the Brazilian College of Radiology (CBR, in the Portuguese acronym) and the Brazilian Federation of Societies of Gynecology and Obstetrics (FEBRASGO, in the Portuguese acronym).

The fetal biometry measurements were BPD, HC, AC, and FL, which were based on previously described methodologies. ${ }^{13-15}$ The amniotic fluid index (AFI) was used to estimate the fluid volume, and was categorized as a dichotomous variable according to whether the values were normal or abnormal. ${ }^{16}$ Intrauterine growth restriction was defined in the present study as weight two standard deviations below the average BW for each GA.

The assessment of blood flow measurements of the resistance index (RI) and PI of the UA, MCA, and ductus venosus (DV) were obtained using a previously described methodology. ${ }^{17-19}$ Brain sparing reflex was considered when the PI of the MCA was below the 5th percentile for GA. The ratio between ventricular systole and atrial contraction (S/A ratio) on the DV was considered abnormal when the values exceeded 3.6, according to the local curve. ${ }^{20}$

Fetal weight was estimated with eleven different formulae using different numbers and combinations of BPD, HC, AC and FL obtained in the literature and available on the ultrasound equipment.

The EFW formulae listed were selected because they are widely used equations in the clinical practice, and because they are represented by fetal biometrics parameters available in routine ultrasound examinations. Formulae described for small fetuses, such as those of Mielke I and II, were not selected because they required the measurement of the transverse diameter of the abdomen, which is not part of the patterns used in the selected health units. The selected formulae are described in detail in - Table 1. ${ }^{21-24}$

The Hadlock formulae are often interchanged in previous studies, according to the understanding of the authors. In the present article, these equations were used according to the detailed description and numbering in -Table 1. Following the birth, neonatologists immediately assisted the newborns. After initial care, birthweights were obtained and registered in scales of $5 \mathrm{~g}$ (Filizola, model BP Baby, São Paulo, SP, Brazil). The Local Ethics Committee approved this study under registration CAAE number 36546014.7.0000.5269.

The descriptive data analysis considered the mean and standard deviation. The formulae for fetal weight estimation listed in -Table $\mathbf{1}$ were compared in terms of means for

Table 1 Formulae for fetal weight estimation

\begin{tabular}{|l|l|l|}
\hline Formula & Parameters & Description \\
\hline Campbell & AC & $\mathrm{e}^{\wedge}\left(-4.564+0.282 \times \mathrm{AC}-0.00331 \times \mathrm{AC} \mathrm{C}^{\wedge}\right)[\mathrm{g}, \mathrm{cm}]$ \\
\hline Hadlock I & $\mathrm{BPD}, \mathrm{HC}, \mathrm{AC}, \mathrm{FL}$ & $\begin{array}{l}10^{\wedge}(1.3596+0.0064 \times \mathrm{HC}+0.0424 \times \mathrm{AC}+0.174 \times \mathrm{FL}+0.00061 \times \mathrm{BPD} \\
\times \mathrm{AC}-0.00386 \times \mathrm{AC} \times \mathrm{FL})[\mathrm{g}, \mathrm{cm}]\end{array}$ \\
\hline Hadlock II & $\mathrm{AC}, \mathrm{FL}$ & $10^{\wedge}(1.304+0.05281 \times \mathrm{AC}+0.1938 \times \mathrm{FL}-0.004 \times \mathrm{AC} \times \mathrm{FL})[\mathrm{g}, \mathrm{cm}]$ \\
\hline Hadlock III & $\mathrm{BPD}, \mathrm{AC}, \mathrm{FL}$ & $10^{\wedge}(1.335-0.0034 \times \mathrm{AC} \times \mathrm{FL}+0.0316 \times \mathrm{BPD}+0.0457 \times \mathrm{AC}+0.1623 \times \mathrm{FL})[\mathrm{g}, \mathrm{cm}]$ \\
\hline Hadlock IV & $\mathrm{HC}, \mathrm{AC}, \mathrm{FL}$ & $10^{\wedge}(1.326-0.00326 \times \mathrm{AC} \times \mathrm{FL}+0.0107 \times \mathrm{HC}+0.0438 \times \mathrm{AC}+0.158 \times \mathrm{FL})[\mathrm{g}, \mathrm{Cm}]$ \\
\hline Hadlock V & $\mathrm{BPD}, \mathrm{AC}$ & $\begin{array}{l}10^{\wedge}(1.1134+0.005845 \times \mathrm{AC}-0.000604 \times \mathrm{AC} 2-0.007365 \times \mathrm{BPD} \wedge 2+0.000595 \\
\times \mathrm{BPD} \times \mathrm{AC}+0.1694 \times \mathrm{BPD})[\mathrm{g}, \mathrm{cm}]\end{array}$ \\
\hline Shepard & $\mathrm{BPD}, \mathrm{AC}$ & $10^{\wedge}(-1.7492+0.166 \times \mathrm{BPD}+0.046 \times \mathrm{AC}-0.002546 \times \mathrm{AC} \times \mathrm{BPD}[\mathrm{kg}, \mathrm{cm}]$ \\
\hline Warsof & $\mathrm{BPD}, \mathrm{AC}$ & $10^{\wedge}(-1.599+0.144 \times \mathrm{BPD}+0.032 \times \mathrm{AC}-0.000111 \times \mathrm{BPD} 2 \times \mathrm{AC})[\mathrm{kg}, \mathrm{cm}]$ \\
\hline Weiner I & $\mathrm{HC}, \mathrm{AC}, \mathrm{FL}$ & $10^{\wedge}(1.6961+0.02253 \times \mathrm{HC}+0.01645 \times \mathrm{AC}+0.06439 \times \mathrm{FL})[\mathrm{g}, \mathrm{cm}]$ \\
\hline Weiner II & $\mathrm{HC}, \mathrm{AC}$ & $10^{\wedge}(1.6575+0.04035 \times \mathrm{HC}+0.01285 \times \mathrm{AC})[\mathrm{g}, \mathrm{cm}]$ \\
\hline Woo III & $\mathrm{BPD}, \mathrm{AC}, \mathrm{FL}$ & $\begin{array}{l}10^{\wedge}(1.54+0.15 \times \mathrm{BPD}+0.00111 \times \mathrm{AC} 2-0.0000764 \times \mathrm{BPD} \times \mathrm{AC} 2+0.05 \\
\times \mathrm{FL}-0.000992 \times \mathrm{FL} \times \mathrm{AC}[\mathrm{g}, \mathrm{cm}]\end{array}$ \\
\hline
\end{tabular}

Abbreviations: AC, abdominal circumference; BPD, biparietal diameter; e, Euler number; FL, femur length; HC, head circumference. Note: Source: Adapted from Abele et al (2010). ${ }^{21}$ 
Table 2 Characteristics of the studied sample

\begin{tabular}{|l|l|}
\hline Maternal age (years), mean \pm SD & $31 \pm 6.2$ \\
\hline Birth weight (grams), mean \pm SD & $918 \pm 361.1$ \\
\hline Gestational age at delivery (weeks), SD & $28,8 \pm 2.3$ \\
\hline $\begin{array}{l}\text { BW }<\text { 3rd percentile, frequency } \\
\text { (percentage) }\end{array}$ & $78(40.2 \%)$ \\
\hline Male sex frequency (percentage) & $103(53.1 \%)$ \\
\hline Abnormal AFI frequency (percentage) & $87(44.8 \%)$ \\
\hline $\begin{array}{l}\text { Doppler UA AREDV frequency } \\
\text { (percentage) }\end{array}$ & $122(62.9 \%)$ \\
\hline $\begin{array}{l}\text { Doppler DV abnormal S/A frequency } \\
\text { (percentage) }\end{array}$ & $60(34.8 \%)$ \\
\hline Stillborn frequency (percentage) & $7(3.6 \%)$ \\
\hline
\end{tabular}

Abbreviations: AFI, amniotic fluid index; AREDV, absent and reversed end-diastolic velocity; BW, birth weight; DV, ductus venosus; S/A, ventricular systole and atrial contraction ratio; SD, standard deviation; UA, umbilical artery.

absolute percentage error $(\mathrm{APE}=\|[$ Estimated weight - Birth weight $] \times 100 /$ Birth weight $\mid$ ). All analyses were performed using the Statistical Package for the Social Sciences (SPSS, IBM Corp., Armonk, NY, US) software, version, 20, and the R ( $R$ Foundation for Statistical Computing, Vienna, Austria) software, version 2.15.1, with a significance level of 0.05 as reference.

A bivariate analysis was performed to compare the mean values for fetal weight estimation obtained with the different formulae with the following variables: growth pattern (appropriate for gestational age [AGA]/IUGR), GA at birth (< 28 weeks, 28-32 weeks, $>32$ weeks), sex (male/female), AFI (normal/abnormal), UA status (normal/abnormal), and DV status (normal/abnormal). These analyses were performed to identify, for each of the equations used, which were related to the observed variations, considering a level of significance of 0.05 .

\section{Results}

In total, 194 patients met the research inclusion criteria. One case was excluded due to inconsistent registration of BPD in the medical record. All fetuses were delivered through cesarean section, except for the stillbirths, which were delivered vaginally. The descriptive analysis of the studied population is summarized in -Table 2.

The average fetal weight estimated through each formula is shown in - Table 3.

For APE, the formulae that demonstrated the best performance in the studied population were Hadlock I, II, III, and IV and Warsof, which had the lowest median values (-Table 4).

The Hadlock IV (HC, AC, FL), Hadlock I (BPD, HC, AC and FL), and Hadlock III (BDP, AC, FL) formulae had the lowest median APE values: 8.17, 8.32, and 8.74 respectively. A mean APE value $<10$ was considered an indicator of satisfactory performance for each formula according to previous reports.

The cohort was divided into 2 groups per fetal growth: AGA, $n=116$ (59.8\%), and IUGR, $n=78$ (40.2\%). Intrauterine growth restriction was defined in the present study as weight two standard deviations below the average BW for each GA.

Regarding the mean APE in AGA fetuses, Hadlock I, II, III, IV, and Warsof formulae demonstrated the best performance (8.02, 8.95, 8.41, 7.87, and 8.72 respectively). Hadlock IV (HC, $\mathrm{AC}, \mathrm{FL}$ ) had the lowest APE value. The same performance was observed in the IUGR fetus population, with a mean APE of $8.77,10.18,9.23,8.62$, and 10.26 respectively, as shown in - Fig. 1. There was no significant difference between the median APE values of the AGA and IUGR groups, which were calculated using the Hadlock I (BPD, HC, AC and FL) and IV (HC, AC, FL) formulae.

The 11 formulae were also compared in groups defined per GA (24-28, 28-32 and 32-34 weeks), sex of the newborn (male or female), AFI ( $<5 \mathrm{~cm}$ or $\geq 5 \mathrm{~cm}$ ), UA Doppler status (PI $>95$ th percentile or absent/reverse diastole), and DV

Table 3 Representation of the 95\% confidence interval of the mean estimated fetal weigth in grams using the eleven formulae

\begin{tabular}{|l|l|l|l|l|l|}
\hline & $\mathbf{n}$ & Minimum & Maximum & Mean & Standard deviation \\
\hline Campbell & 194 & 282.31 & $3,312.29$ & 981.6658 & 450.65413 \\
\hline Hadlock I & 193 & 318.5 & $2,032.9$ & 910.569 & 368.9429 \\
\hline Hadlock II & 194 & 305.0 & $2,382.2$ & 909.611 & 375.9173 \\
\hline Hadlock III & 194 & 320.7 & $2,127.4$ & 918.754 & 374.0832 \\
\hline Hadlock IV & 193 & 317.7 & $2,042.4$ & 909.641 & 366.9738 \\
\hline Hadlock V & 194 & 345.4 & $2,246.0$ & 983.673 & 409.3975 \\
\hline Shepard & 194 & 373.8 & $2,264.5$ & $1,008.021$ & 419.2746 \\
\hline Warsof & 194 & 359.6 & $1,966.5$ & 920.546 & 370.5401 \\
\hline Weiner I & 193 & 348.4 & $1,657.7$ & 840.630 & 298.8425 \\
\hline Weiner II & 193 & 312.6 & $1,862.8$ & 883.734 & 307.7843 \\
\hline Woo III & 194 & 375.2 & $2,092.7$ & 949.585 & 385.2960 \\
\hline
\end{tabular}


Table 4 Performance of the eleven formulae for fetal weight estimation, expressed as the mean absolute percentage error (APE)

\begin{tabular}{|l|l|l|l|l|l|}
\hline & $\mathbf{n}$ & Minimum & Maximum & Mean APE & Standard deviation \\
\hline Campbell & 194 & 0.01 & 99.54 & 13.8099 & 12.81752 \\
\hline Hadlock I & 193 & 0.02 & 42.94 & 8.3193 & 7.32916 \\
\hline Hadlock II & 194 & 0.05 & 47.86 & 9.4487 & 8.56320 \\
\hline Hadlock III & 194 & 0.01 & 46.86 & 8.7386 & 7.69347 \\
\hline Hadlock IV & 193 & 0.11 & 41.88 & 8.1745 & 7.23123 \\
\hline Hadlock V & 194 & 0.02 & 48.81 & 11.5152 & 9.73483 \\
\hline Shepard & 194 & 0.22 & 47.98 & 13.4033 & 10.14293 \\
\hline Warsof & 194 & 0.00 & 45.49 & 9.3412 & 8.05797 \\
\hline Weiner I & 193 & 0.05 & 33.24 & 9.7163 & 6.66733 \\
\hline Weiner II & 193 & 0.01 & 37.21 & 9.5477 & 7.40668 \\
\hline Woo III & 194 & 0.27 & 44.35 & 10.0275 & 8.15756 \\
\hline
\end{tabular}

(normal or altered). The Hadlock formulae demonstrated no statistically significant difference in performance in the subgroup analysis per neonate sex, GA at birth, AFI, UA, or DV status (- Table 5). The resulting table shows the existence or not of statistical association, considering a level of significance of 0.05 .

\section{Discussion}

This study compared eleven formulae for fetal weight estimation in the clinical context of placental insufficiency observed on Doppler scan. This is a frequent pathology in pregnancy that is associated with an increased risk of growth restriction and low BW..$^{2,3,8,11}$ It is an original study in Brazil.

The formulae with the best performance for fetal weight estimation in the analyzed population were Hadlock I (BPD,

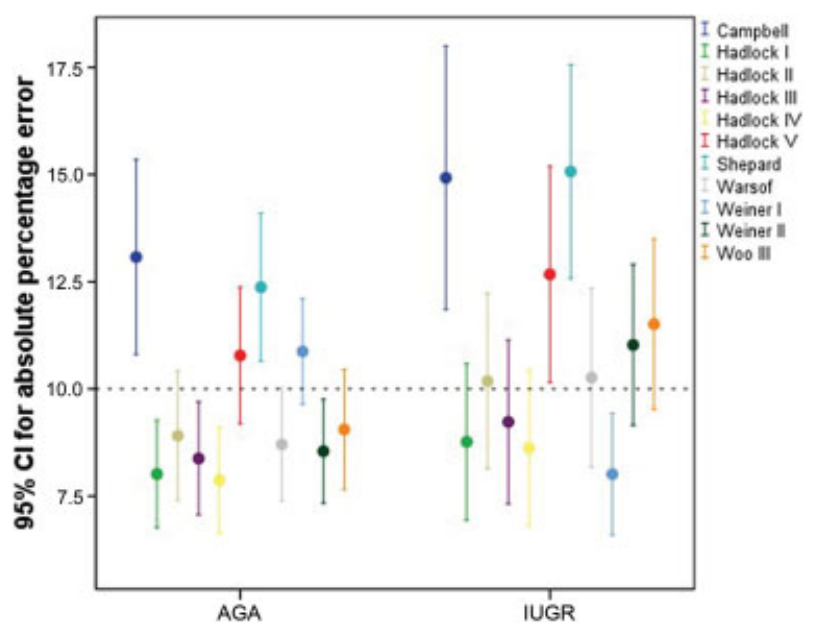

Fig. 1 Graphical representation of the mean absolute percentage error for the 11 formulae and their respective $95 \%$ confidence intervals according to the pattern of fetal growth. Abbreviations: $\mathrm{Cl}$, confidence interval; APE, absolute percentage error; AGA, appropriate for gestational age; IUGR, intrauterine growth restriction.
HC, AC and FL) and IV (HC, AC and FL), which use four and three fetal biometric parameters respectively, based on the mean APE. This finding is consistent with what has already been documented in the medical literature for specific populations such as very premature fetuses and those with growth restriction. ${ }^{21,22,24-35}$ The formulae with the poorest performance in our population were Campbell and Shepard.

The Hadlock formulae did not significantly differ in performance in the analyses according to fetal growth, fetal sex, GA at birth, AFI, UA, and DV status. ${ }^{22}$ This finding is similar to those obtained by studies that assessed cases of extreme prematurity for any reason and pregnancies with specific conditions such as preeclampsia. ${ }^{21,22}$

The final fetal biometry measurement for the ultrasound weight estimation was obtained at least five days before birth. The last Doppler velocimetry measurement was

Table 5 Influence of the clinical/ultrasonographic parameters on the average of the absolute percentage error for each formula

\begin{tabular}{|l|l|l|l|l|l|l|}
\hline Formula & $\begin{array}{l}\text { Growth } \\
\text { pattern }\end{array}$ & $\begin{array}{l}\text { GA at } \\
\text { birth }\end{array}$ & Sex & AFI & $\begin{array}{l}\text { UA } \\
\text { status }\end{array}$ & $\begin{array}{l}\text { DV } \\
\text { status }\end{array}$ \\
\hline Campbell & No & Yes & Yes & No & Yes & No \\
\hline Hadlock I & No & No & No & No & No & No \\
\hline Hadlock II & No & No & No & No & No & No \\
\hline Hadlock III & No & No & No & No & No & No \\
\hline Hadlock IV & No & No & No & No & No & No \\
\hline Hadlock V & No & No & No & No & Yes & No \\
\hline Shepard & No & No & No & No & Yes & No \\
\hline Warsof & No & No & No & No & No & No \\
\hline Weiner I & Yes & No & Yes & No & No & No \\
\hline Weiner II & No & No & No & No & No & No \\
\hline Woo III & No & No & No & No & No & No \\
\hline
\end{tabular}

Abbreviations: AFI, amniotic fluid index; DV, ductus venosus; GA, gestational age; UA, umbilical artery. 
performed in all patients no more than 24 hours before birth. This can be considered a particular strength of the study, because these parameters are more accurate than what is commonly found in the literature, which is a range of up to seven days between the last ultrasound examination and delivery. ${ }^{21,22,25,26}$ Another quality that should be emphasized is the fact that the present study included a relatively large cohort, composed of 194 patients.

The study has some limitations that should be addressed. Only formulae based on BPD, HC, AC, and/or FL with circumferences measured by ellipsis were included; thus, the present findings cannot be extrapolated to formulae that use other parameters. ${ }^{27}$ We did not make adjustments for the interval between EFW and BW because this period was not longer than five days. This is a retrospective study; therefore, it carries a risk of loss of information due to flaws in medical records.

More studies, preferably with prospective designs and larger sample sizes, are necessary to corroborate the findings presented here, minimizing possible biases and enabling the extrapolation of the findings.

\section{Conclusion}

The present study demonstrated the variability of performance among eleven different formulae for weight estimation in premature fetuses who experienced changes in blood flow. Our results indicate that the Hadlock formulae that use three (HC, AC and FL) or four (BPD, HC, AC and FL) biometric fetal parameters have the best results for this specific fetus population. Despite the reports of formulae designed specifically for premature and/or IUGR fetuses in the literature, the Hadlock I (BPD, HC, AC and FL) and IV (HC, $A C$ and $F L$ ) formulae had fewer errors regarding BW in our study population. In addition, this better performance was not influenced by the clinical and ultrasound factors frequently present in early-onset placental insufficiency. Thus, considering the possible biases of this type of study design, our results indicate that the Hadlock I (BPD, HC, AC and FL) and IV (HC, AC and FL) formulae can be applied with satisfactory performance for fetal weight estimation in a population of fetuses with early-onset severe placental insufficiency.

\section{Conflict of Interests}

The authors have none to declare.

\section{References}

1 Ricci AG, Brizot MdeL, Liao AW, Nomura RM, Zugaib M. [Ultrasonographic accuracy of fetal weight estimation and influence of maternal and fetal factors]. Rev Bras Ginecol Obstet 2011;33(09): 240-245. Doi: 10.1590/S0100-72032011000900004

2 Abuhamad AZ. The role of Doppler ultrasound in obstetrics. In: Callen PW, ed. Ultrasonography in Obstetrics and Gynecology. $5^{\text {th }}$ ed. Philadelphia, PA: Saunders Elsevier; 2011:794-807

3 Unterscheider J, Daly S, Geary MP, et al. Optimizing the definition of intrauterine growth restriction: the multicenter prospective PORTO Study. Am J Obstet Gynecol 2013;208(04):290.e1-290.e6. Doi: 10.1016/j.ajog.2013.02.007
4 Nardozza LMM, Araújo Junior E, Vieira MF, Rolo LC, Moron AF. Estimativa de peso ao nascimento utilizando a ultrassonografia bidimensional e tridimensional. Rev Assoc Med Bras (1992) 2010; 56(02):204-208. Doi: 10.1590/S0104-42302010000200020

5 Baschat AA. Doppler application in the delivery timing of the preterm growth-restricted fetus: another step in the right direction. Ultrasound Obstet Gynecol 2004;23(02):111-118. Doi: 10.1002/uog.989

6 Nelson DB, Ziadie MS, McIntire DD, Rogers BB, Leveno KJ. Placental pathology suggesting that preeclampsia is more than one disease. Am J Obstet Gynecol 2014;210(01):66.e1-66.e7. Doi: 10.1016/j.ajog.2013.09.010

7 Baschat AA, Gembruch U, Harman CR. The sequence of changes in Doppler and biophysical parameters as severe fetal growth restriction worsens. Ultrasound Obstet Gynecol 2001;18(06): 571-577. Doi: 10.1046/j.0960-7692.2001.00591.x

8 Moreira Neto AR, Córdoba JCM, Peraçoli JC. Etiologia da restrição do crescimento intrauterino (RCIU). Comun Ciênc Saúde 2011;22:21-30

9 Robson SC, Martin WL, Morris RK. The investigation and management of the small-for-gestational-age fetus. London: RCOG; 2013

10 Seravalli V, Baschat AA. A uniform management approach to optimize outcome in fetal growth restriction. Obstet Gynecol Clin North Am 2015;42(02):275-288. Doi: 10.1016/j.ogc.2015.01.005

11 Unterscheider J, O'Donoghue K, Daly S, et al. Fetal growth restriction and the risk of perinatal mortality-case studies from the multicentre PORTO study. BMC Pregnancy Childbirth 2014;14:63. Doi: 10.1186/1471-2393-14-63

12 Carvalho PRN, Sá RAM, Gomes SC Jr, Lopes LM, Moreira MEL. Evaluation of Hadlock's formula in premature fetuses with severe Doppler abnormalities. J Perinat Med 2011;39:1-5

13 Campbell S, Wilkin D. Ultrasonic measurement of fetal abdomen circumference in the estimation of fetal weight. Br J Obstet Gynaecol 1975;82(09):689-697. Doi: 10.1111/j.1471-0528.1975.tb00708.x

14 O'Brien GD, Queenan JT, Campbell S. Assessment of gestational age in the second trimester by real-time ultrasound measurement of the femur length. Am J Obstet Gynecol 1981;139(05): 540-545. Doi: 10.1016/0002-9378(81)90514-7

15 Shepard M, Filly RA. A standardized plane for biparietal diameter measurement. J Ultrasound Med 1982;1(04):145-150. Doi: 10.78 63/jum.1982.1.4.145

16 Phelan JP, Smith CV, Broussard P, Small M. Amniotic fluid volume assessment with the four-quadrant technique at 36-42 weeks' gestation. J Reprod Med 1987;32(07):540-542

17 Arduini D, Rizzo G. Normal values of Pulsatility Index from fetal vessels: a cross-sectional study on 1556 healthy fetuses. J Perinat Med 1990;18(03):165-172. Doi: 10.1515/jpme.1990.18.3.165

18 Rizzo G, Capponi A, Talone PE, Arduini D, Romanini C. Doppler indices from inferior vena cava and ductus venosus in predicting $\mathrm{pH}$ and oxygen tension in umbilical blood at cordocentesis in growthretarded fetuses. Ultrasound Obstet Gynecol 1996;7(06):401-410. Doi: 10.1046/j.1469-0705.1996.07060401.x

19 Wladimiroff JW, Tonge HM, Stewart PA. Doppler ultrasound assessment of cerebral blood flow in the human fetus. Br J Obstet Gynaecol 1986;93(05):471-475. Doi: 10.1111/j.1471-0528.1986.tb08656.x

20 Sá RAM, Chaves Netto H, Amim J Jr, et al. Ductus venosus velocimetry in normal pregnancy. Int J Gynaecol Obstet 2000; 70(S1):A28. Doi: 10.1016/S0020-7292(00)82042-1

21 Abele H, Hoopmann M, Wagner N, Hahn M, Wallwiener D, Kagan KO. Accuracy of sonographic fetal weight estimation of fetuses with a birth weight of $1500 \mathrm{~g}$ or less. Eur J Obstet Gynecol Reprod Biol 2010;153(02):131-137. Doi: 10.1016/j.ejogrb.2010.07.007

22 Geerts L, Widmer T. Which is the most accurate formula to estimate fetal weight in women with severe preterm preeclampsia? J Matern Fetal Neonatal Med 2011;24(02):271-279. Doi: 10.3109/14767058.2010.485232

23 Woo JS, Wan CW, Cho KM. Computer-assisted evaluation of ultrasonic fetal weight prediction using multiple regression equations with and without the fetal femur length. J Ultrasound Med 1985;4(02):65-67 
24 Blumenfeld YJ, Lee HC, Pullen KM, Wong AE, Pettit K, Taslimi MM. Ultrasound estimation of fetal weight in small for gestational age pregnancies. J Matern Fetal Neonatal Med 2010;23(08):790-793. Doi: $10.3109 / 14767050903387052$

25 Hadlock FP, Harrist RB, Sharman RS, Deter RL, Park SK. Estimation of fetal weight with the use of head, body, and femur measurements-a prospective study. Am J Obstet Gynecol 1985;151(03): 333-337. Doi: 10.1016/0002-9378(85)90298-4

26 Anderson NG, Jolley IJ, Wells JE. Sonographic estimation of fetal weight: comparison of bias, precision and consistency using 12 different formulae. Ultrasound Obstet Gynecol 2007;30(02):173-179

27 Smulian JC, Ranzini AC, Ananth CV, Rosenberg JC, Vintzileos AM. Comparison of three sonographic circumference measurement techniques to predict birth weight. Obstet Gynecol 1999;93(5 Pt 1):692-696. Doi: 10.1016/S0029-7844(98)00517-1

28 Dudley NJ. A systematic review of the ultrasound estimation of fetal weight. Ultrasound Obstet Gynecol 2005;25(01):80-89. Doi: 10.1002/uog.1751

29 Kurmanavicius J, Burkhardt T, Wisser J, Huch R. Ultrasonographic fetal weight estimation: accuracy of formulas and accuracy of examiners by birth weight from 500 to $5000 \mathrm{~g}$. J Perinat Med 2004;32(02):155-161. Doi: 10.1515/JPM.2004.028
30 Medchill MT, Peterson CM, Kreinick C, Garbaciak J. Prediction of estimated fetal weight in extremely low birth weight neonates (500-1000 g). Obstet Gynecol 1991;78(02):286-290

31 Burd I, Srinivas S, Paré E, Dharan V, Wang E. Is sonographic assessment of fetal weight influenced by formula selection? J Ultrasound Med 2009;28(08):1019-1024. Doi: 10.7863/ jum.2009.28.8.1019

32 Jouannic JM, Grangé G, Goffinet F, Benachi A, Carbrol D. Validity of sonographic formulas for estimating fetal weight below 1,250 g: a series of 119 cases. Fetal Diagn Ther 2001;16(04):254-258. Doi: $10.1159 / 000053923$

33 Shamley KT, Landon MB. Accuracy and modifying factors for ultrasonographic determination of fetal weight at term. Obstet Gynecol 1994;84(06):926-930

34 Siemer J, Egger N, Hart N, et al. Fetal weight estimation by ultrasound: comparison of 11 different formulae and examiners with differing skill levels. Ultraschall Med 2008;29(02):159-164. Doi: 10.1055/s-2007-963165

35 Townsend RR, Filly RA, Callen PW, Laros RK. Factors affecting prenatal sonographic estimation of weight in extremely low birthweight infants. J Ultrasound Med 1988;7(04):183-187. Doi: 10.7863/jum.1988.7.4.183 